Agrovoc descriptors: insect nematodes, pest insects, steinernema, biological control, identification, pest control, dna, classification

Agris category code: $\mathrm{H} 10, \mathrm{P} 34$

\title{
First record of a cold-active entomopathogenic nematode Steinernema kraussei (Steiner) (Rhabditida: Steinernematidae) in Slovenia
}

\author{
Žiga LAZNIK ${ }^{1}$, Tímea TÓTH ${ }^{2}$, Tamás LAKATOS ${ }^{3}$, Matej VIDRIH ${ }^{4}$, Stanislav TRDAN ${ }^{5}$
}

Received September 22, 2008; accepted April 2, 2008.

Delo je prispelo 22. septembra 2008, sprejeto 2. april 2008.

\begin{abstract}
In preceding researches on occurrence of entomopathogenic nematodes in Slovenia, which started in 2007, we already recorded Steinernema affine (Bovien), S. feltiae (Filipjev) and S. carpocapsae (Weiser). In April 2008, 120 soil samples from 24 locations were collected in Gorenjska, Notranjska and Primorska regions as well as in Ljubljansko barje. The presence of entomopathogenic nematodes was confirmed in 9 samples from 6 locations. Only the sample C46, which was taken in the village Podbrezje in Gorenjska region, was sent to genetic analysis. Molecular biological analysis have proved the identity of the sample with the species Steinernema kraussei (Steiner). This was the first record of Steinernema kraussei in Slovenia.
\end{abstract}

Key words: entomopathogenic nematodes, Slovenia, Steinernema affine, Steinernema feltiae, Steinernema carpocapsae, Steinernema kraussei, biological control

\section{IZVLEČEK}

PRVA NAJDBA ENTOMOPATOGENE OGORČICE Steinernema kraussei (Steiner) (Rhabditida: Steinernematidae) V SLOVENIJI

$\mathrm{V}$ predhodnih raziskavah preučevanja razširjenosti entomopatogenih ogorčic v Sloveniji, ki potekajo od leta 2007, smo ugotovili zastopanost vrst Steinernema affine (Bovien), Steinernema feltiae (Filipjev) in Steinernema carpocapsae (Weiser). V aprilu 2008 smo na območjih Gorenjske, Notranjske, Primorske in Ljubljanskega barja na 24 lokacijah nabrali 120 talnih vzorcev. Zastopanost entomopatogenih ogorčic smo ugotovili v 9 vzorcih z 6 lokacij. V nadaljnjo genetsko analizo smo poslali le vzorec C46. Ta je bil odvzet $\mathrm{v}$ vasi Podbrezje na Gorenjskem. Z molekulsko analizo smo identificirali vrsto Steinernema kraussei (Steiner). Gre za prvo odkritje omenjene vrste entomopatogene ogorčice pri nas.

Ključne besede: entomopatogene ogorčice, Slovenija, Steinernema affine, Steinernema feltiae, Steinernema carpocapsae, Steinernema kraussei, biotično varstvo

\section{INTRODUCTION}

Entomopathogenic nematodes (EPNs) from genera Steinernema Travassos and Heterorhabditis Poinar are obligatory parasites of numerous insects (Ishibashi and
Choi, 1991). They live in symbiotic relationship with bacteria from genera Xenorhabdus and Photorhabdus (Forst et al., 1997). Momentarily, 70 species of EPNs

\footnotetext{
${ }^{1}$ Jamnikarjeva 101, SI-1111 Ljubljana, email: ziga.laznik@bf.uni-lj.si

${ }^{1}$ Vadastag 2, H-4244 Újfehértó, Hungary

${ }^{1}$ Vadastag 2, H-4244 Újfehértó, Hungary

4 Jamnikarjeva 101, SI-1111 Ljubljana

${ }^{5}$ Jamnikarjeva 101, SI-1111 Ljubljana
} 
are classified into families Steinernematidae (56 species) and Heterorhabditidae (14 species) (Yilmaz et al., 2008).

EPNs are cosmopolitan animals, while we can find them on all continents, with the exception of Antarctica (Griffin et al., 1991; Hominick, 2002). Although EPNs are pathogenic to many pest insect species (Poinar, 1979), their successful commercial application is limited to relatively low number of insects (Grewal and Georgis, 1999; Shapiro-Ilan et al., 2002).

Application of EPNs in biological control was traditionally engaged in controlling soil pests until some years ago (Ishibashi and Choi, 1991). Results from researches in the last two decades indicate also their potential against foliar pests, but only under special conditions (Arthurs et al., 2004). Poorer efficacy of EPNs in controlling foliar pests is a consequence of unsuitable (too low) moisture (Lello et al., 1996), exposure to extreme temperatures (Grewal et al., 1994), and ultraviolet radiation (Gaugler and Boush, 1978). These factors are known as crucial for survival of the nematodes (Kaya, 1990). For this reason the efficacy of EPNs in the open is therefore often worser as expected, although predecessor laboratory tests shows rather better efficacy (Buitenhuis and Shipp, 2005).

In the last period biological potential of EPNs has influenced the large number of new investigations, in which scientists want to find new species of EPNs and their symbiotic bacteria (Hominick et al., 1996; Mráček et al., 2006; Nguyen et al., 2006; Tóth and Lakatos, 2008); with a desire to also study other topics, which are indirectly or directly connected with the efficiency of EPNs in biological control of insect pests: biodiversity, ecology, evolution, biochemistry, symbiosis and molecular genetics (Burnell in Stock, 2000; Li et al., 2007).

At the moment there are some companies on the market, which generate bioproducts on the basis of EPNs (Willmott et al., 2002). In biological control of pests in plant protection limited number of EPNs is commercialy available: Steinernema feltiae, $S$. carpocapsae, S. kraussei, S. riobrave, S. scapterisci, Heterorhabditis bacteriophora in $H$. megidis $H$. marelata, $H$. zealandica). Due to before mentioned facts, it is important to study domestic soil fauna on the occurrence of EPNs, while in many countries these organisms are treated as exotic organisms and therefore their application is limited to laboratory researches.

In Slovenia, momentarily only entomopathogenic nematodes Steinernema feltiae and S. carpocapsae have a status of indigenous species (MAFFab, 2008, Laznik et al., 2008bc); therefore only this two nematodes can be applied in the field. With the researches, which results we also present in this paper, we want to enlist as more species of entomopathogenic nematodes as it is possible, while in foreign countries they worth as alternatives to insecticides in controling pest insects. The strain C46 (Steinernema kraussei), which we present in a current paper, we plan to use in extensive experiments in the future; first in the laboratory and afterward, when its status will be administratively entrenched, also in the field.

\section{MATERIALS AND METHODS}

In April 2008, we examined 120 soil samples from 24 different locations on the occurrence of EPNs in Slovenia. The soil samples, five from each sampling place, were taken in Gorenjska, Notranjska and Primorska regions as well as in Ljubljansko barje. We used »Galleria bait method«, which is the most frequently used method for EPNs detection from soil. After the death of greater wax moth (Galleria mellonella [Linnaeus]) larvae, we dried cadavers for 12 days and put them in so-called »white trap « (Bedding and Akhurst, 1975) to separate the nematodes from death larvae. The suspension, which was acquired in this way, was used for artificial infection of the larvae of greater wax moth. Following procedure contained the use of centrifuge and $5 \%$ concentration of sodium hypochlorate. The aim of this process was to acquire infective juveniles from the suspension. We confirmed the presence of the nematodes in 9 soil samples from 6 locations. Only 1 positive sample, C46 (taken in the forest near village Podbrezje in Gorenjska region [N Slovenia, $46^{\circ} 17^{\prime} \mathrm{N}, 14^{\circ} 16^{\prime} \mathrm{E}, 403 \mathrm{~m}$ alt.] was identified to this time.

\section{RESULTS}

To confirm the identification of isolated nematodes from larvae of wax moth, a selected sample was analysed by molecular biological approach. Genomic DNA was extracted from individual nematodes and PCR was performed to multiply ITS region using primers TW81 and AB28 after Hominick et al. (1997). PCR product were reisolated from $1 \%$ TAE-buffered agarose gel using QIAquick Gel Extraction Kit (Qiagen, USA) (Fig. 1). Reisolated sample was sequenced in the laboratory of Biological Research Centre in Szeged, 
First record of a cold-active entomopathogenic nematode Steinernema kraussei (Steiner) (Rhabditida:...

Hungary. The sequence was submitted into GenBank public database (Accession Number: EU914856). Sample DNA sequence was compared to sequences of species Steinernema using BLAST search in National Centre for Biotechnology Information (NCBI) web site (www.ncbi.nlm.nih.gov). The sequences producing significant alignments and at least $99 \%$ identity were derived from Steinernema kraussei: GenBank Accession No. AY230175 and AY171264 (Spiridonov et al., 2004) (Fig. 2).

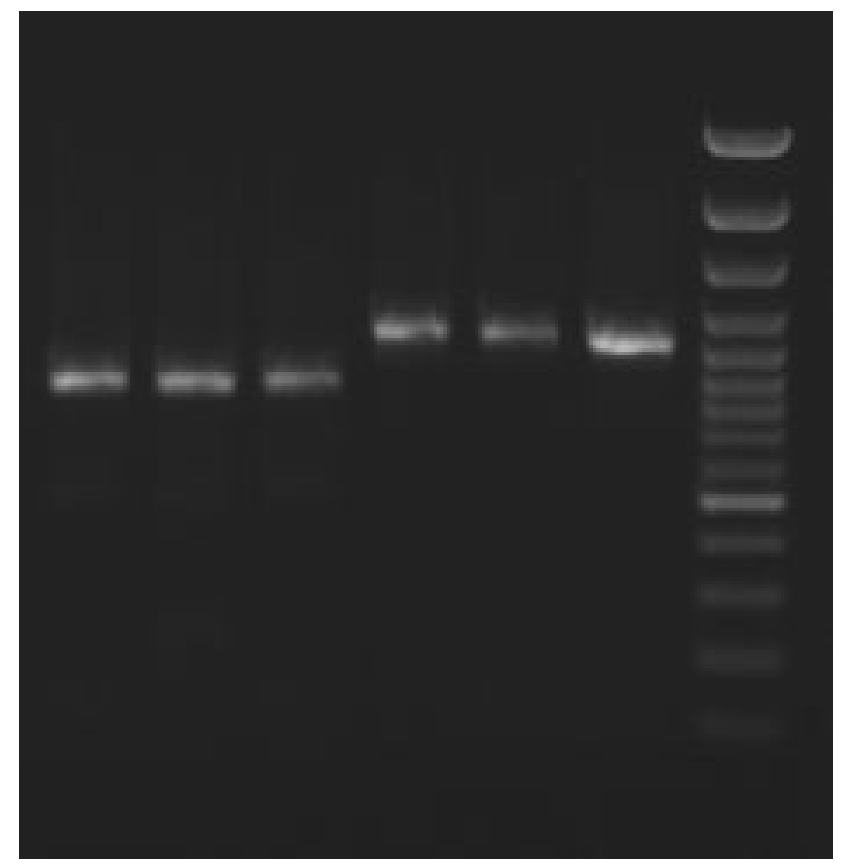

Figure 1: 1\% TAE buffered agarose gel, in the $7^{\text {th }}$ lane: GeneRuler 100 bp DNA Ladder Plus (Fermentas), in the $4^{\text {th }}$, $5^{\text {th }}$ and $6^{\text {th }}$ lane: PCR product of our sample C46, using the primer pair specified in the text. The two most strength fragment in the ladder are 500 and 1000 bps length.

\begin{tabular}{|c|c|c|c|}
\hline EU914856 & 1 & GAGCTTATCCATTT - CTTGGCTTCAAATGAATCGAGCTGAATC - TTTGCTG - TCTGTTTC & 57 \\
\hline AY230175 & 195 & $\ldots \ldots \ldots \ldots \ldots$ А. $А$ А. $\ldots \ldots \ldots \ldots \ldots \ldots \ldots-\ldots \ldots-$ Т. $\ldots$ & 252 \\
\hline 71264 & 3 & 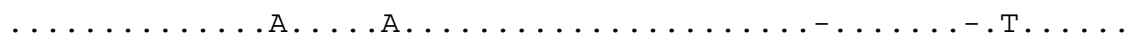 & 60 \\
\hline DQ375757 & 175 & 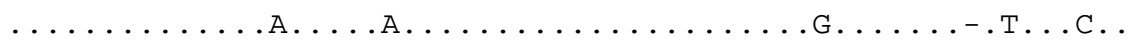 & 233 \\
\hline ј914856 & 8 & GAAGCGATGTATTCTCTCAACAAACGGCTATGAAGGGTTTCTGTAGGTGTCTGGAGCAGT & 117 \\
\hline Y230175 & 253 & 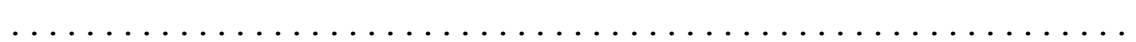 & 312 \\
\hline 171264 & 61 & . & 120 \\
\hline Q375757 & 234 & $\ldots \ldots$.Т. ...... . . . А... & 293 \\
\hline J914856 & 118 & TGTATGTGCGTGACTGTGGTGATG - GACATTTGAGTTCTTCTGGAACTAGAATTAAAGAA & 176 \\
\hline Y230175 & 313 & 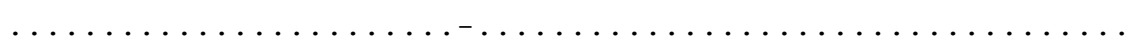 & 371 \\
\hline Y171264 & 121 & $\ldots \ldots \ldots$ & 179 \\
\hline Q375757 & 294 & $\ldots G .-$. & 350 \\
\hline J914856 & 177 & GTCTGTTACGACTCGCCGTTCTT - AAAAAACTTCAATTAACGTTTGAACAATTTGACTGC & 235 \\
\hline AY230175 & 372 & 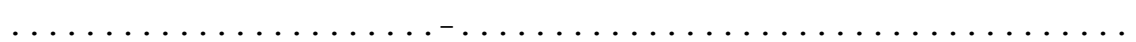 & 430 \\
\hline AY171264 & 180 & $\ldots C$. & 238 \\
\hline DQ375757 & 351 & 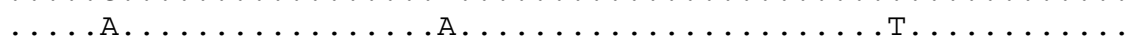 & 410 \\
\hline EU914856 & 236 & ACCAGCCGTAGGTGTAATTAAAGATTTATCAAGTCTTGTCGGTGGATCACTCGGTTCGTA & 295 \\
\hline AY230175 & 431 & $\ldots \ldots \ldots \ldots \ldots \ldots \ldots \ldots \ldots \ldots$ & 490 \\
\hline AY171264 & 239 & & 298 \\
\hline DQ375757 & 411 & . C. & 470 \\
\hline & 0 & GTTCGATGAAAAACGGGGCAAAAACCGTTATTTGGCGTGAATTGCAGACATATTGAACGC & 355 \\
\hline ( & & 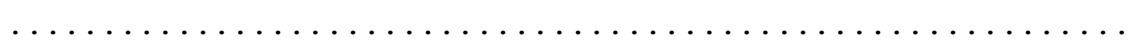 & 550 \\
\hline
\end{tabular}




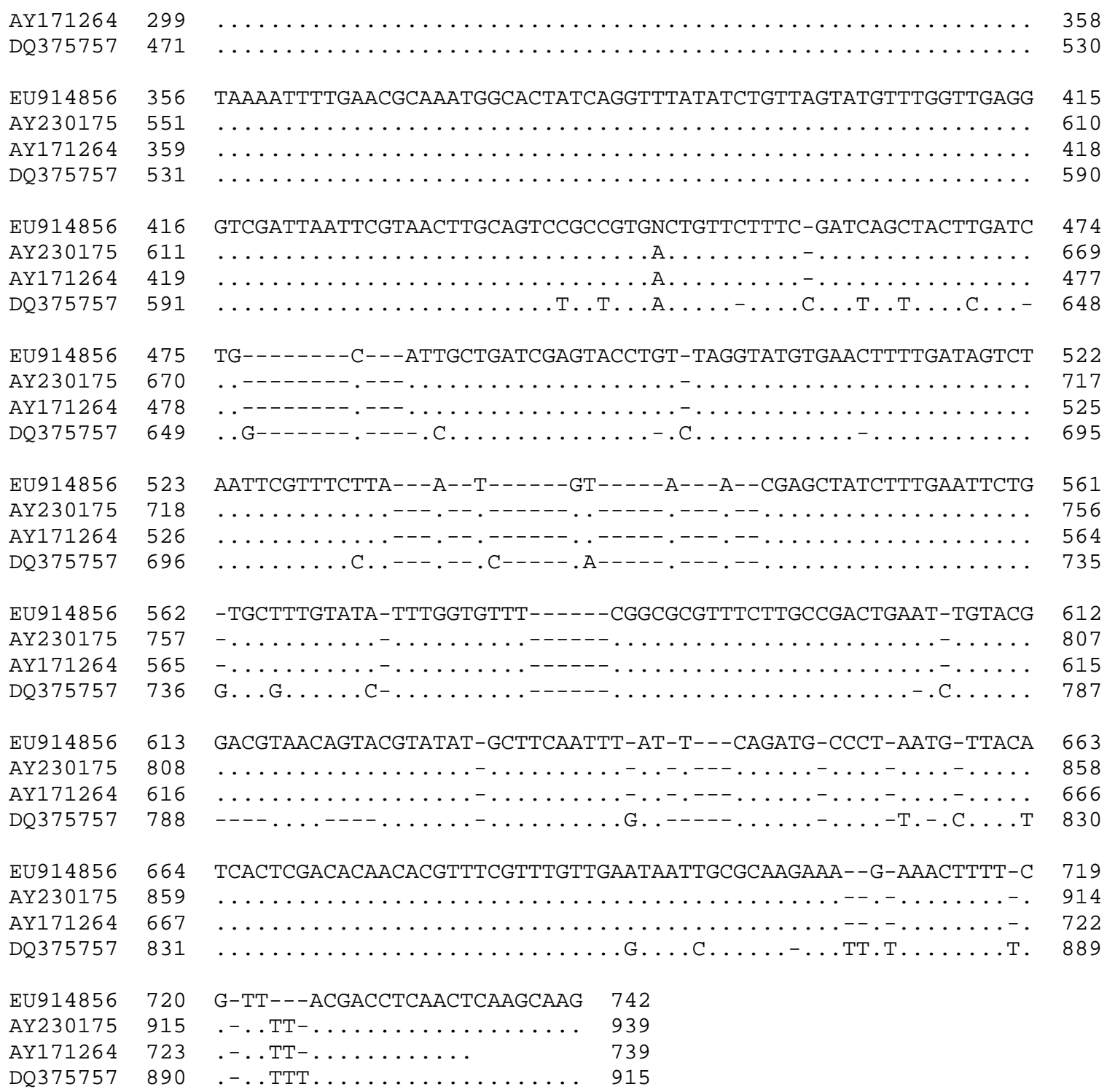

Figure 2: Multiple sequence alignment of the ITS rDNA region (including partial fragments of the 18S and 28S rDNA genes) of 4 Steinernema species. Code EU914856 correspond to the Slovenian isolate of Steinernema kraussei (C46). Codes AY230175 and AY171264 are Steinernema kraussei strains from Germany and Russia. Code DQ375757 correspond to Steinernema akhursti strain from China.

\section{DISCUSSION}

Genetic studies proved that the nematode species is Steinernema kraussei (Steiner, 1923). The ITS1-5.8SITS2 region, including the partial $18 \mathrm{~S}$ and $28 \mathrm{~S}$ rRNA genes (flanked by above primers) of Slovenian isolate C46, is 742 bp long. BLAST searches (Altschul et al., 1990) in GenBank showed that Slovenian isolate C46 (Fig. 1) has a high similarity (99\%) with those sequences available for S. kraussei populations (e.g. accession numbers AY230175 and AY171264). Sequence of other species from feltiae group, namely $S$. akhursti was obtained from GenBank searches that exhibited a lesser degree of similarity with the Slovenian isolate and other S. kraussei populations (e.g. accesion number DQ375757) (Fig. 1). The present study constitutes the first report of $S$. kraussei in Slovenia. In Europe, until now S. kraussei was already recorded in Austria, Belgium, Great Britain, Czech Republic, Germany, Slovakia, Switzerland, Island, Norway, Spain in Bulgaria and in many other parts of the world (for a detailed EPN species distribution see Hominick, 2002). 
We can place mentioned species into »feltiae group« of nematodes from genus Steinernema (Nguyen, 2006); for infective juveniles it is known that they are between 700 and $1000 \mu \mathrm{m}_{-}$long. This nematode lives in symbiosis with bacterium Xenorhabdus bovienii (Boemare and Akhurst, 1988; Fischer-Le Saux et al., 1998). It is Steinernema kraussei, the first recorded EPN species (Glaser and Fox, 1923), when attack and death by this EPN was observed in Japanese beettle (Popillia japonica Newman). In the same year Steiner renamed this species to Aplectana kraussei, but in 1927 Travassos changed the original name of the genus and used the name Steinernema (Laznik in Trdan, 2008a).

Numerous researches showed that $S$. kraussei is efficient at low temperature (from 6 to $10^{\circ} \mathrm{C}$ ) (Long et al., 2000). It was mainly studied when controlling black vine weevil (Otiorhynchus sulcatus [Fabricious]) and they have found out also over $80 \%$ efficiency at low temperature; meanwhile some other species ( $S$. carpocapsae, S. feltiae and $H$. megidis) have not shown satisfying efficiency (Long et al., 2000; Willmott et al., 2002; Haukeland, 2007). Efficacy of S. kraussei in low temperature has a big importance in plant protection, specially when applying in the open, while temperature, beside UV radiation and moisture, represents the most important limiting factor aforesaid biological agents (Kaya, 1990).

After the first record of Steinernema kraussei in Slovenia, we expect that the use of these biological agents against insect pests will become important alternative to insecticides. These will be especially desired against the pests, which is not easy to control with insecticides, due to their massive occurrence in the period of harvesting, against the pests, which are resistant to insecticides etc. In the future experiments, C46 strain of S. kraussei, will be used against different agricultural pests under laboratory conditions as well as in the open field.

\section{ACKNOWLEDGEMENTS}

This work is a part of program Horticulture No P40013-0481 granted by Slovenian Research Agency, and the part of project CRP V4-0524 granted by Slovenian
Research Agency and Ministry of Agriculture, Food and Forestry of R Slovenia.

\section{REFERENCES}

Altschul S.F., Gish W., Miller W., Myers E.W., Lipman D.J. 1990. Basic local alignment search tool. J. Mol. Biol. 215: $403-410$

Arthurs S., Heinz K.M., Prasifka J.R. 2004. An analysis of using entomopathogenic nematodes against above-ground pests. Bull. Entomol. Res. 94: 297-306.

Bedding R.A., Akhurst R.J. 1975. Simple technique for the detection of insect parasitic rhabditid nematodes in soil. Nematologica 21: 109-110.

Boemare, N.E. and Akhurst, R.J. 1988. Biochemical and physiological characterization of colony form variants in Xenorhabdus spp. (Enterobacteriaceae). J. General Microbiol. 134: 751-761.

Buitenhuis R., Shipp J.L. 2005. Efficacy of entomopathogenic nematode Steinernema feltiae (Rhabditida: Steinernematidae) as influenced by Frankliniella occidentalis (Thysanoptera: Thripidae) developmental stage and host plant stage. J. Econ. Entomol. 98: 14801485 .

Burnell, A.M. and Stock, S.P. 2000. Heterorhabditis, Steinernema and their bacterial symbionts-lethal pathogenc of insects. Nematology 2, 31-42.

Fischer-Le Saux, M., Mauléon, H., Constant, P., Brunel, B., Boemare, N.E. 1998. PCR-ribotyping of Xenorhabdus and Photorhabdus isolates from the Caribbean region in relation to the taxonomy and geographic distribution of their nematode hosts. Appl. Environ. Microbiol. 64: 4246-4254.

Forst, S., Dowds, B., Boemare, N. E., Stackebrandt, E. 1997. Xenorhabdus spp. and Photorhabdus spp.: bugs that kill bugs. Annu. Rev. Microbiol. 51: 47-72.

Gaugler R., Boush G.M. 1978. Effects of ultraviolet radiation and sunlight on the entomopathogenous nematode, Neoaplectana carpocapsae. J. Invertebr. Pathol. 32: 291296.

Grewal, P.S., Selvan S., Gaugler R. 1994. Thermal adaptation of entomopathogenic nematodes: niche breadth for infection, establishment, and reproduction. J. Therm. Biol. 19: 245-253.

Grewal, P., Georgis, R. 1999. Entomopathogenic nematodes. In: Hall, F.R., Menn, J.J. (Eds.), Methods in Biotechnology, Biopesticides: Use and Delivery, vol. 5. Humana Press, Totowa, NJ, pp. 271-299.

Griffin, C.Z., Downes, M.J., Block, W. 1991. Tests of Antarctic soils for insect-parasitic nematodes. Antarct. Sci. 2: 221-222.

Haukeland, S. 2006. Using entomopathogenic nematodes against Otiorhynchus in field grown strawberries - does it work? Bulletin OILB/SROP. International Organization for Biological and Integrated Control of Noxious Animals and Plants (OIBC/OIBL), West

Acta agriculturae Slovenica, 93 - 1, maj 2009 
Palaearctic Regional Section (WPRS/SROP), Dijon, France; 2006. 29: 37-39.

Hominick W.M. 2002. Biogeography. In: Gaugler R (ed) Entomopathogenic Nematology. CABI Publishing, Wallingford, pp. 115-143.

Hominick, W.M., Reid, A.P., Bohan, D.A., Briscoe, .R. 1996. Entomopathogenic nematodes: biodiversity, geographical distribution and convention on biological diversity. Biocontrol Sci. Technol. 6, 317.332.

Hominick W.M., Briscoe B.R., del Pino F.G., Heng J., Hunt D.J., Kozodoy E., Mracek Z., Nguyen K.B., Reid A.P., Spiridonov S., Stock P., Sturhan D., Waturu C., Yoshida M. 1997. Biosystematics of entomopathogenic nematodes: current status, protocols and definitions. J. Helminthol. 71: 271-298.

Ishibashi N., Choi D.-R. 1991. Biological control of soil pests by mixed application of entomopathogenic and fungivorous nematodes. J. Nematology 23: 175-181.

Kaya H.K. 1990. Soil ecology. In: Gaugler R and Kaya HK (eds.) Entomopathogenic Nematodes in Biological Control, CRC Press, Florida, pp. 93-115.

Laznik, Ž and Trdan, S. 2008a. Entomopathogenic nematodes, natural enemies of foliar pests of vegetable brassicas. Acta Agric. Slov.: 91, 227-237. [Slovenian]

Laznik, Ž., Tóth, T., Lakatos, T., Trdan, S. $2008 \mathrm{~b}$. Entomopathogenic nematode Steinernema feltiae (Filipjev) (Rhabditida: Steinernematidae) recorded for the first time in Slovenia. Acta Agric. Slov., 91: 37-45.

Laznik, Ž., Tóth, T., Lakatos, T., Trdan, S. 2008c. Entomopathogenic nematode Steinernema carpocapsae (Weiser) (Rhabditida:Steinernematidae), a new member of Slovenian fauna. Acta Agric. Slov. (in press)

Lello E.R., Patel M.N., Mathews G.A., Wright D.J. 1996. Application technology for entomopathogenic nematodes against foliar pests. Crop Prot. 15: 567-574.

Li, X.-Y., Cowles, R.S., Cowles, E.A., Gaugler, R., CoxFoster, D.L. 2007. Relationship between the successful infection by entomopathogenic nematodes and the host immune response. Int. J. Parasitol. 69: 246-252.

Long, S.J., Richardson, P.N., Fenlon, J.S. 2000. Influence of temperature on the infectivity of entomopathogenic nematodes (Steinernema and Heterorhabditis spp.) to larvae and pupae of the vine weevil Otiorhynchus sulcatus (Coleoptera: Curculionidae). Nematology, 2: 309-317.

Ministry of Agriculture, Food, and Forestry of Republic Slovenia [MAFFa]. 2008: Decision on the change of the status of the exotic agent for biological control (no. 34309/2008/5): 2 p. [Slovenian]
Ministry of Agriculture, Food, and Forestry of Republic Slovenia [MAFFb]. 2008: Decision on the change of the status of the exotic agent for biological control (no. 3430583/2008/2): 2 p. [Slovenian]

Mráček, Z., Nguyen, K.B., Tailliez, P., Boemare, N., Chen, S.L. 2006. Steinernema sichuanense n. sp. (Rhabditida: Steinernematidae), a new species of entomopathogenic nematode from the province of Sichuan, east Tibetan Mts., China. J. Invert. Pathol. 93, 157-169.

Nguyen K.B. 2006. Entomopathogenic Nematodes. Entomology and Nematology Department (31. jan. 2006) http://kbn.ifas.ufl.edu/kbnstein.htm (21.11.2007)

Nguyen, K.B., Gozel, U., Köppenhöfer, H.S., Adams, B.J. 2006. Heterorhabditis floridensis n. sp. (Rhabditida: Heterorhabditidae) from Florida. Zootaxa, 1177: 1-19.

Poinar, G.O.Jr. 1979. Nematodes for the biological control of insects. Boca Raton, FL, USA, CRC Press, 227 pp.

Shapiro-Ilan, D.I., Gouge, D.H., Köppenhöfer, A.M. 2002. Factors affecting commercial success: case studies in cotton, turf and citrus. In: Gaugler, R. (Ed.), Entomopathogenic Nematology. CABI, New York, pp. 333-356.

Spiridonov, S. E., Reid, A. P., Podrucka, K., Subbotin, S. A., Moens, M. 2004. Phylogenetic relationship within the genus Steinernema (Nematoda: Rhabditida) as inferred from analyses of sequences of ITS1-5.8S-ITS2 region of the rDNA and morphological features. Nematology, 6: 547-566.

Steiner, G. 1923. Aplectana kraussei n. sp., eine in der Blattwespe Lyda sp. parasitierende Nematodenform, nebst Bemerkungen über das Seitenorgan der parasitcischen Nematoden. Zentralblatt für Bakteriologie, Parasitenkunde, Infektionskrankenheiten und Hygiene, Abteilung 2, 14-18.

Tóth, T. and Lakatos, T. 2008. A new subspecies of Photorhabdus temperata, isolated from Heterorhabditis nematodes: Photorhabdus temperata subsp. cinerea subsp. nov. Int. J. Syst. Evol. Microbiol. (in press).

Willmott, D.M., Hart, A.J., Long, S.J., Edmondson, R.N., Richardson, P.N. 2002. Use of a cold-active entomopathogenic nematode Steinernema kraussei to control overwintering larvae of the black vine weevil Otiorhynchus sulcatus (Coleoptera: Curculionidae) in outdoor strawberry plants. Nematology, 4: 925-932.

Yilmaz, H., Waeyenberge, L., Demir, I., Demirbag, Z., Moens, M. 2008. Distribution of Entomopathogenic Nematodes from the Eastern Black Sea Region of Turkey. Book of Abstracts of $60^{\text {th }}$ International Symposium on Crop Protection, May 20, Gent, Belgium. pp 199. 